\title{
Identification and Characterization of Bacterial Community Associated with the Chewed Feeding Waste of Red Palm Weevil in Infested Date Palm Trees
}

\author{
AbdulAziz M. A. Mohamed1,2, Muhammad Farooq1, Malabika Roy Pathak ${ }^{1 *}$ \\ ${ }^{1}$ Agricultural Biotechnology Program, Department of Life Sciences, Arabian Gulf University, Manama, Kingdom of Bahrain \\ ${ }^{2}$ Agricultue Affairs, Ministry of Works, Municipalities Affairs and Urban Planning, Manama, Kingdom of Bahrain \\ Email: amabdulkareem@gmail.com, *malabikarp@agu.edu.bh
}

How to cite this paper: Mohamed, A.M.A., Farooq, M. and Pathak, M.R. (2020) Identification and Characterization of Bacterial Community Associated with the Chewed Feeding Waste of Red Palm Weevil in Infested Date Palm Trees. Advances in Bioscience and Biotechnology, 11, 80-93. https://doi.org/10.4236/abb.2020.113007

Received: January 27, 2020

Accepted: March 27, 2020

Published: March 30, 2020

Copyright $\odot 2020$ by author(s) and Scientific Research Publishing Inc. This work is licensed under the Creative Commons Attribution International License (CC BY 4.0).

http://creativecommons.org/licenses/by/4.0/ (c) (i) Open Access

\begin{abstract}
Red palm weevil (RPW), Rhynchophorus ferrugineus (Olivier) (Coleoptera, Curculionidae), is considered one of the most damaging insect pests of date palms in the Kingdom of Bahrain. Large scale infestation of RPW to date palm trees leads to excessive feeding activity of the RPW larvae, which is carried out by microorganisms present within RPW and producing a wet fermenting material inside the trunk. Culture dependent-bacteria were isolated from feeding waste and identified by the sequencing of the $16 \mathrm{~S}$ rRNA gene using $8 \mathrm{~F}$ and $1492 \mathrm{R}$ universal primers. Among the culture-dependent isolated bacteria, $80 \%$ were identified by comparing $16 \mathrm{~S}$ rRNA gene sequence in NCBI database, using BLAST program in GenBank. $85 \%$ of the identified bacteria were Gram-positive while the rest of them were Gram-negative. A high abundance of bacteria were from the Bacillaceae family and sixteen different species of Bacillus were identified in comparison with NCBI GenBank. The 16S rRNA gene sequences of identified bacterial strains have been submitted to GenBank. The phylogenetic relationship was studied using 16S rRNA gene sequences, the Gram-negative bacteria came in one clade while Gram-positive different Bacillus sp. and strains showed evolutionary closeness to each other and accordingly, they came in one major clade under three different sub-clades in the phylogenetic tree. The findings of new Bacillus strains in the natural habitat of the date plam trees in the Kingdom of Bahrain, pledge a vast area of research on RPW bio-control research arena.
\end{abstract}

\section{Keywords}

Red Palm Weevil (RPW), Bacteria, Date Palm, Feeding Waste, 16S rRNA 


\section{Introduction}

The red palm weevil (RPW), Rhynchophorus ferrugineus Olivier (Coleoptera: Curculionidae), is considered one of the most extensively dispersed and invasive pest of different palm genera around the globe while date palm is one of them [1]. RPW was first reported on coconut palm trees (Cocos nucifera) from South and Southeast Asia in the late 1980s. Gradually, the pest expanded its spread to the Middle East, Mediterranean basin, Africa, Europe, Australia, Caribbean islands and USA [2] [3] [4] [5]. Date palm (Phoenix dactylifera, L. Arecales: Arecaceae), is socio-economically important monocotyledon woody perennial plant in the Kingdom of Bahrain. Currently, the main threat of the date palm trees in the country is the red palm weevil, Rhynchophorus ferrugineus (Olivier) (Coleoptera, Curculionidae). The red palm weevil (RPW) is an invasive wood-boring insect that has caused severe damage since its first introduction and attack of date palm trees in the mid-1990s in the Kingdom of Bahrain [6] [7]. The RPW is one of the most destructive pests of date palms, the major fruit tree of arid, tropical and subtropical areas [8]. RPW is considered one of the serious pests for many palm species in the world, and withstand extreme weather [9] [10].

Being a boring insect, adult RPW penetrates the date palm stem and feed on it. Insect infestation alters the health of palm trees by making hollow tunnels with brownish waste inside the trunk and finally kills the trees. So, the severely infested palms are susceptible to collapse [11]. The attack of RPW leads to the death of date palms within 6 - 8 months if untreated [12]. Wood feeding is known for their complex associations with a variety of microorganisms [13] [14]. The substantial environmental and economic injury caused by this insect may be partially attributable to the symbiotic association of bacteria [15]. The gut microbiota of weevils harbor rich communities of symbiotic bacteria, play an important role in weevils digestive system and nutrient absorption [16] [17]. Moreover, there is a report on the seasonal variation of weevil gut microbiota [18].

RPW larvae eat heartily within the apical growing point of the palms and produce wet fermented chewed waste material inside the tunnels and creating extensive damage [19] [20]. A healthy, unfermented palm sap contains glucose and sucrose and lacking organic volatiles [21]. However, when it is exposed to bacteria, they use this sugar as substrate to produce fermented chewed waste that contains alcohols, ethyl esters, carbolic acids, acetate and Sulphur compounds and cause the unpleasant odor of the palm sap [22]. The feeding activity of larvae is mediated by facultative and obligate bacteria with fermentative metabolism was reported [14] [15]. The isolation of three different Bacillus spp. was the only report from RPW infested date plam plants in Egypt [23]. Despite the huge damage caused by RPW and its larvae in date palms, very little is acknowledged internationally with no study about microbiota of its habitat in the Kingdom of Bahrain. Therefore, the study of the microbial community in the habitat of the RPW needs investigation that may help the development of biological control measure of RPW population in the Kingdom of Bahrain. The identification of 
microbial community by using amplification of $16 \mathrm{~S}$ rRNA: encoding DNA (rDNA) or 16S rRNA by PCR has revealed immense phylogenetic diversity [24] [25] [26]. The 16S rRNA molecules are of valued phylogenetic marker for microorganisms because of their universal distribution, constant function and sequence variation [10] [16]. Therefore, the goal of our study is to identify the culture-dependent bacterial community using PCR amplification of the $16 \mathrm{~S}$ rRNA region and sequence analysis from chewed waste of RPW, collected from infested date palm trees.

\section{Materials and Methods}

\subsection{Sampling of RPW Chewed Waste}

The chewed waste of RPW (Figure 1) was used in all the experiments those were collected (28th December 2017) from trunk of infested date palm plantation located in Hoorat A'ali, Northern Governorate, Kingdom of Bahrain (Latitude: 26.167612 Longitude: 50.527532). Collected chewed materials stored at $4^{\circ} \mathrm{C}$ for analysis.

\subsection{Processing of Chewed Waste for Culture Initiation}

One gram of chewed waste was homogenized in $10 \mathrm{ml}$ sterile distilled water following three different serial dilutions for plating in two different culture media; potato dextrose agar, Sigma Aldrich (PDA) and Luria-Bertani Agar, Difco ${ }^{\mathrm{TM}}$ Miller (LBA).

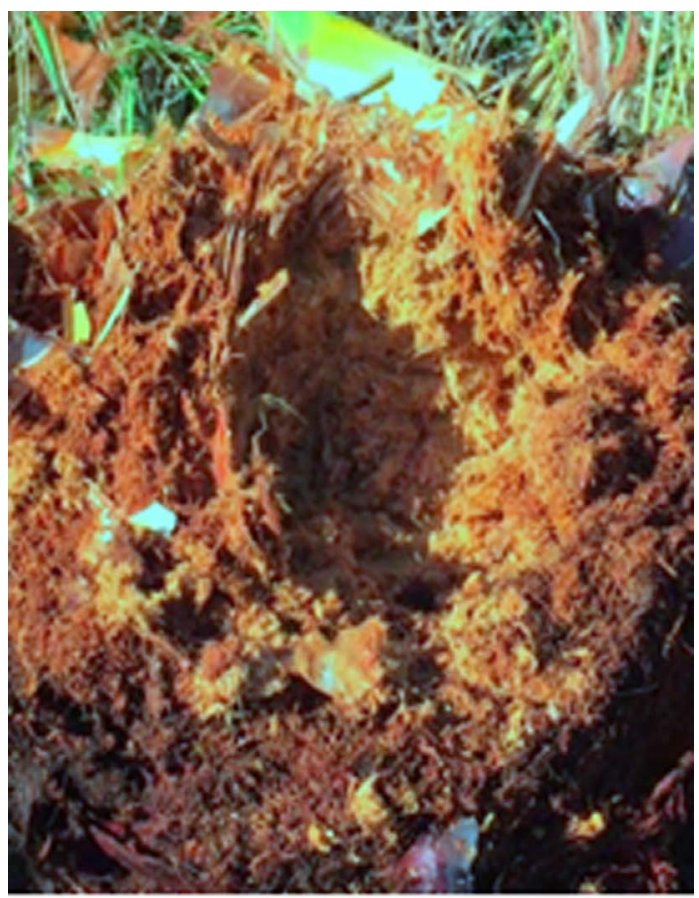

Figure 1. Red palm weeivel infestation in date plam tree from where the chewed feeding waste of RPW was collected. 


\subsection{Culture of Bacteria}

Inoculum from three different dilutions was plated on PDA and LBA media. All plates were incubated at $37^{\circ} \mathrm{C}$ for $72 \mathrm{hrs}$. Different bacterial colonies were clearly observed on all the plates (Figure 2(a)). Bacteria from the individual colony were isolated and sub-cultured separately in corresponding PDA and LBA media overnight (Figure 2(b)).

\subsection{Storage of Bacteria}

Bacteria from each individual colony were further allowed to grow in LB broth and incubated on shaker at $37^{\circ} \mathrm{C}$ at a speed of $150 \mathrm{rpm}$ for overnight growth. Culture from each isolate was stored in $50 \%$ glycerol and stored in $-80^{\circ} \mathrm{C}$ for further use.

\subsection{Identification of Bacteria}

At the first step of identification, all of the bacterial isolates were examined morphologically using standard Gram staining technique. Stained slides of bacteria were differentiated as Gram positive/negative class of bacteria using microscopic technique under $(100 \times)$ with oil immersion.

\subsection{Extraction of DNA}

DNA was isolated from freshly grown overnight culture. The genomic DNA was isolated using kit (XG-2411-00), following the manufacturer's instructions. The purity of the extracted DNA was confirmed by $1 \%$ agarose gel by visualization of DNA bands.

\subsection{PCR Amplification of the 16S rRNA Gene}

Isolated DNAs of all bacteria were amplified with $16 \mathrm{~S}$ rRNA specific universal primers 8F and 1492R (Table 1). The amplification was carried out in ABI Veriti
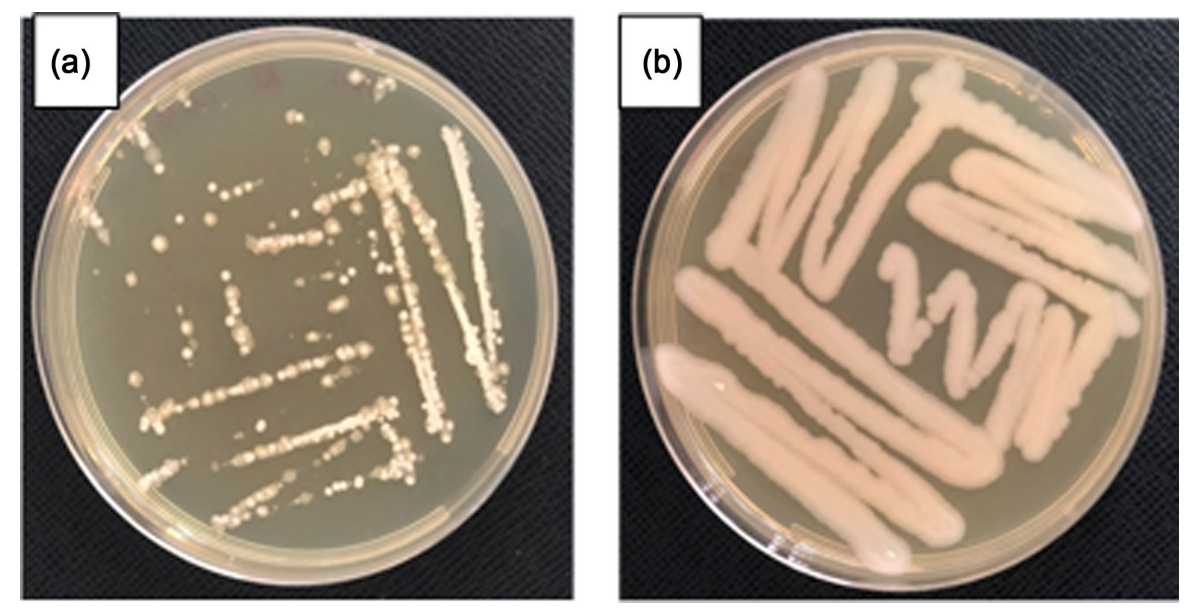

Figure 2. (a) PDA plate showing growth of bacterial colonies after 72 hours of growth at $37^{\circ} \mathrm{C}$. (b) PDA plate showing subculture of individual colony after 24 hours of growth at $37^{\circ} \mathrm{C}$. 
Thermal Cycler at initial denaturation $94^{\circ} \mathrm{C}$ for $3 \mathrm{~min}, 35$ cycles of $94^{\circ} \mathrm{C} 30 \mathrm{sec}$, $52^{\circ} \mathrm{C} 30 \mathrm{sec}$, and $72^{\circ} \mathrm{C} 1 \mathrm{~min}$, and a final extension at $72^{\circ} \mathrm{C}$ for $7 \mathrm{~min}$ (Table 2). 1.2\% Agarose gel was used to check the PCR amplified products. After visualization of amplified products under UV light using the gel documentation system (Zenith Biosciences, Figure 3(a), Figure 3(b)) were processed further for sequencing.

Table 1. Composition and concentration of reagents used in reaction mixture for PCR of $16 \mathrm{~S}$ rRNA gene amplification of culture dependent bacteria isolated from chewed waste of RPW.

\begin{tabular}{ccc}
\hline Sr. & Reagents & Volume per Reaction $(\mu \mathrm{l})$ \\
\hline 1 & DNA $(25 \mathrm{ng})$ & $1.0 \mu \mathrm{l}$ \\
2 & 8F Forward Primer $(10 \mathrm{pM})$ & $1.0 \mu \mathrm{l}$ \\
3 & 1492R Reverse Primer $(10 \mathrm{pM})$ & $1.0 \mu \mathrm{l}$ \\
4 & 2X PCR Master Mix & $12.5 \mu \mathrm{l}$ \\
5 & Nuclease Free Water & $9.5 \mu \mathrm{l}$ \\
& Total Volume & $25 \mu \mathrm{l}$ \\
\hline
\end{tabular}

Table 2. List of primers, their sequences and annealing temperature used in PCR amplification of 16SrRNA gene of culture dependent bacteria isolated from feeding waste of RPW chewed waste.

\begin{tabular}{|c|c|c|c|c|c|c|}
\hline Gene & $\begin{array}{c}\text { PCR } \\
\text { Primers }\end{array}$ & Primer Sequence 5'-3' & $\begin{array}{l}\text { Annealing } \\
\text { Temp. }\end{array}$ & $\begin{array}{l}\text { Sequencing } \\
\text { Primer }\end{array}$ & $\begin{array}{l}\text { Target } \\
\text { group }\end{array}$ & Reference \\
\hline \multirow{2}{*}{$\begin{array}{c}16 \mathrm{~S} \\
\text { rRNA }\end{array}$} & $8 \mathrm{~F}$ & AGAGTTTGATCCTGGCTCAG & $52^{\circ} \mathrm{C}$ & $8 \mathrm{~F}^{\star}$ & \multirow{2}{*}{ Universal } & Turner et al., \\
\hline & $1492 \mathrm{R}$ & GGTTACCTTGTTACGACTT & $52^{\circ} \mathrm{C}$ & $1492 \mathrm{R}^{*}$ & & 1999 \\
\hline
\end{tabular}

${ }^{*}$ Bi-directional sequencing.

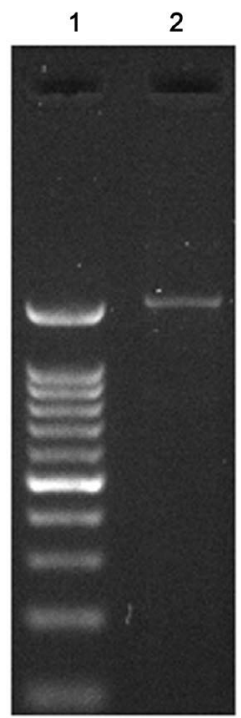

(a)

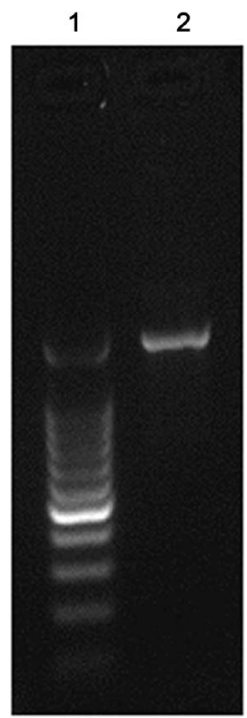

(b)

Figure 3. 1.2\% Agarose gel showing single $1500 \mathrm{bp}$ of $16 \mathrm{~S}$ rDNA amplicon of two different bacteria ((a), (b)). Lane 1: 100 bp DNA ladder; Lane 2: 16S rDNA amplicon. 


\subsection{Sequencing of $16 \mathrm{~S}$ rRNA Gene}

PCR amplicons were purified and sequenced using BDT v3.1, cycle sequencing kit on ABI 3730xl Genetic Analyzer (Applied Biosystems, USA), bi-directionally using $8 \mathrm{~F}$ and $1492 \mathrm{R}$ primers. The sequencing used was set as $95^{\circ} \mathrm{C}$ for $3 \mathrm{~min}$ and $25 \mathrm{cycles}$ of $\left(95^{\circ} \mathrm{C}\right.$ for $5 \mathrm{sec}, 55^{\circ} \mathrm{C}$ for $5 \mathrm{sec}$, and $60^{\circ} \mathrm{C}$ for $\left.4 \mathrm{~min}\right)$. Sequences were aligned using Codoncode aligner.

\subsection{Analysis of Sequences}

The obtained 16S rRNA gene sequences of each isolate were used to carry out the BLAST analysis in NCBI Genbank database. Based on the maximum identity score, using multiple alignment software program ClustalW, sequences were compared. The 16S rRNA gene sequences of successful isolates were deposited in GenBank (Table 4).

\section{Results}

\subsection{Gram Stain and Bacteria}

RPW feeding waste contained an average of $1.2-1.9 \times 10^{9} \mathrm{CFU} / \mathrm{ml}$ of bacteria in the serially diluted culture used for study. Twenty four culturable bacterial isolates were studied by Gram staining, among which 16 were Gram-positive (Figure 4(a)) and 8 were Gram-negative (Figure 4(b)). Gram-positive bacteria appeared as a purple-colored stain (Figure 4(a)) by taking crystal violet stain after washing, due to thick peptidoglycan layer of their cell wall. On the other hand, Gram-negative bacteria cannot retain the crystal violet stain after washing, due to their much thinner and sandwiched nature of peptidoglycan layer of their cell wall (Figure 4(b)).

\subsection{Identification of Culturable Bacteria from Chewed Waste of RPW}

DNA were isolated and PCR amplified from all the culturable bacteria using $16 \mathrm{~S}$ rRNA specific universal primers $8 \mathrm{~F}$ and $1492 \mathrm{R}$ for identification as mentioned in
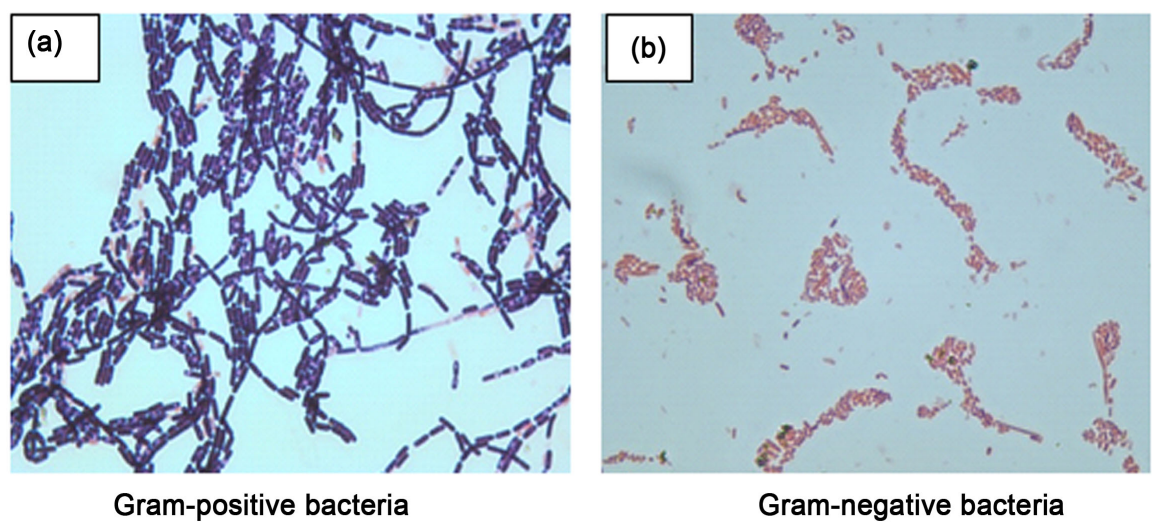

Figure 4. Gram Stained slides differentiated cultured bacteria as grampositive (a) and negative (b) of bacteria under $100 \times$ power with oil immersion in microscope. 
Table 1. The PCR amplification was carried out following the conditions as mentioned in Table 2. 1.2\% Agarose gel showed a single amplified DNA products of $1500 \mathrm{bp}$ of all different bacterial isolatesas shown in Figure 3(a) and Figure 3(b) (only two different bacteria has presented). But, the bidirectional DNA sequencing products of PCR amplicons (1500 bp) of different bacterial isolates varied in sequencing results from $1316 \mathrm{bp}$ to $1461 \mathrm{bp}$ and showed in $\mathrm{Ta}$ ble 3. Bacterial DNA isolated from chewed waste of RPW was identified using $16 \mathrm{~S}$ rRNA gene sequence by BLAST alignment in NCBI site. The success of obtaining of sequence was $91.66 \%$ in this study. Bacteria were identified based on maximum sequence identity level in GenBank. Finally, 79.16\% bacteria were identified using the BLAST program in reference to GenBank accession numbers (NCBI) which have been presented. The level of sequence identity percent varied from 94 to 100.

Table 3. List of cultured bacteria, isolated from chewed waste of RPW were identified using 16SrRNA gene sequence by BLAST alignment in NCBI site. Bacteria were identified based on maximum sequence identity (\%) level and NCBI accession numbers of compared bacteria have been presented.

\begin{tabular}{|c|c|c|c|c|c|}
\hline $\begin{array}{l}\text { Seq. } \\
\text { ID }\end{array}$ & $\begin{array}{l}\text { Sample } \\
\text { ID }\end{array}$ & $\begin{array}{l}\text { Sequence } \\
\text { Size (bp) }\end{array}$ & Bacteria Showed Identity & $\begin{array}{c}\text { Maximum } \\
\text { Identity } \\
(\%)\end{array}$ & $\begin{array}{l}\text { Accession } \\
\text { Number of } \\
\text { Compared } \\
\text { Bacteria in } \\
\text { NCBI GenBank }\end{array}$ \\
\hline 1 & A1 & 1387 & Bacillus cereus strain DM- 5 & 97 & MF967405.1 \\
\hline 2 & A2 & 1374 & Bacillus tequilensis strain HBUM07078 & 99 & MF662504.1 \\
\hline 3 & A3 & 1342 & Bacillus pumilus strain $\mathrm{O} 32$ & 99 & MG594819.1 \\
\hline 4 & A4 & 1340 & Bacillus xiamenensis strain OOM58 & 100 & MH542300.1 \\
\hline 5 & A5 & 1435 & Bacillus altitudinis strain pk5 & 99 & MH538127.1 \\
\hline 6 & A6 & 1359 & Bacillus pumilus strain $2216 \mathrm{E}-\mathrm{X}-48$ & 100 & MF594160.1 \\
\hline 7 & A7 & 1400 & Bacillus wiedmannii strain $\mathrm{K} 3$ & 99 & MK696254.1 \\
\hline 8 & A8 & 1462 & Bacillus altitudinis strain FJAT-4778 & 99 & MG651124.1 \\
\hline 10 & B1a & 1461 & Bacillus wiedmannii strain MOB-9 & 96 & MH041258.1 \\
\hline 11 & B2 & 1374 & Bacillus aerius $\mathrm{R} 1.13$ & 100 & LC414168.1 \\
\hline 12 & B2a & 1374 & Bacillus stratosphericus strain MVGA162 & 100 & KJ672346.1 \\
\hline 13 & B3 & 1386 & Bacillus velezensis strain JK-XZ8 & 99 & MK182932.1 \\
\hline 14 & B4 & 1316 & Bacillus sp. SC24 & 98 & KU353549.1 \\
\hline 16 & B6 & 1411 & $\begin{array}{l}\text { Achromobacter xylosoxidans strain } \\
\text { R8-558 }\end{array}$ & 98 & JQ659958.1 \\
\hline 17 & $\mathrm{C} 1$ & 1419 & Bacillus methylotrophicus strain HGPY-3 & 99 & KR708855.1 \\
\hline 18 & $\mathrm{C} 2$ & 1360 & $\begin{array}{l}\text { Bacillus amyloliquefaciens strain } \\
\text { HTTM-X9894 }\end{array}$ & 99 & KJ733016.1 \\
\hline 19 & $\mathrm{C} 3$ & 1366 & Bacillus siamensis strain FL45 & 99 & KY818963.1 \\
\hline 21 & $\mathrm{C} 5$ & 1366 & Acetobacter ghanensis strain SKU7 & 94 & АВ906410.1 \\
\hline 24 & D3 & 1432 & Vibrio alginolyticus strain NBRC 15630 & 99 & NR_122059.1 \\
\hline
\end{tabular}




\subsection{Identified Bacteria and Phylogeny}

The 16S rRNA gene sequence of identified bacteria has been submitted to NCBI GenBank and their sequence size, name and accession numbers have been presented in Table 4. The comparison of sequences with the global multiple sequence alignment (MSA), and the identification and submission of sequences in NCBI GenBank were adopted in this study. Sixty six percent of the identified bacteria were Gram-positive while the rest of them were Gram-negative. In the study, $86 \%$ of the bacteria were of different Bacillus species of different strains (Phylum: Firmicutes) and 14\% were other bacteria (Achromobacter xylosoxidans strain MPF-B6, Acetobacter ghanensis strain MPF-C5, Vibrio alginolyticus strain MPF-D3). The Gram-positive Bacillus spp. (Family, Bacillaceae) belongs to Phylum Firmicutes and Gram-negative bacteria were of Proteobactera from three different families. The molecular phylogenic affinity was analyzed using sequences of $16 \mathrm{~S}$ rRNA and a phylogenetic tree was constructed in Figure 5. The

Table 4. List of GenBank (NCBI) accession number of culture dependent bacteria, isolated from chewed waste of RPW from RPW infested date palm tree in the Kingdom of Bahrain. The bacteria were identified based on $16 \mathrm{~S}$ rRNA gene sequences.

\begin{tabular}{|c|c|c|c|c|c|}
\hline $\begin{array}{l}\text { Seq. } \\
\text { ID. }\end{array}$ & $\begin{array}{l}\text { Sample } \\
\text { ID }\end{array}$ & Gram Stain & $\begin{array}{l}\text { Sequence } \\
\text { Size (bp) }\end{array}$ & Name of Identified Bacteria & $\begin{array}{l}\text { Accession } \\
\text { Number of } \\
\text { Identified } \\
\text { Bacteria }\end{array}$ \\
\hline 1 & A1 & Gram positive & 1387 & Bacillus cereus strain MPF-A1 & MK9491150 \\
\hline 2 & A2 & Gram positive & 1374 & Bacillus tequilensis strain MPF-A2 & MK949341 \\
\hline 3 & A3 & Gram positive & 1342 & Bacillus pumilus strain MPF-A3 & MK949342 \\
\hline 4 & A4 & Gram positive & 1340 & Bacillus xiamenensis strain MPF-A4 & MK949343 \\
\hline 5 & A5 & Gram positive & 1435 & Bacillus altitudinis strain MPF-A5 & MK949344 \\
\hline 6 & A6 & Gram positive & 1359 & Bacillus pumilus strain $M P F-A 6$ & MK949345 \\
\hline 7 & A7 & Gram positive & 1400 & Bacillus wiedmannii strain MPF-A7 & MK949346 \\
\hline 8 & A8 & Gram positive & 1462 & Bacillus altitudinis strain MPF-A8 & MK949347 \\
\hline 10 & B1a & Gram positive & 1461 & Bacillus wiedmannii strain MPF-B1a & MK949348 \\
\hline 11 & $\mathrm{~B} 2$ & Gram positive & 1374 & Bacillus aerius strain MPF-B2 & MK949349 \\
\hline 12 & $\mathrm{~B} 2 \mathrm{a}$ & Gram positive & 1374 & Bacillus stratosphericus strain MPF-B2a & MK949350 \\
\hline 13 & B3 & Gram positive & 1386 & Bacillus velezensis strain MPF-B3 & MK949351 \\
\hline 14 & B4 & Gram positive & 1316 & Bacillus sp. strain MPF-B4 & MK949352 \\
\hline 16 & B6 & Gram negative & 1411 & $\begin{array}{l}\text { Achromobacter xylosoxidans strain } \\
\text { MPF-B6 }\end{array}$ & MK949353 \\
\hline 17 & $\mathrm{C} 1$ & Gram positive & 1419 & $\begin{array}{l}\text { Bacillus methylotrophicus strain } \\
\text { MPF-C1 }\end{array}$ & MK949354 \\
\hline 18 & $\mathrm{C} 2$ & Gram positive & 1360 & $\begin{array}{l}\text { Bacillus amyloliquefaciens strain } \\
\text { MPF-C2 }\end{array}$ & MK949355 \\
\hline 19 & $\mathrm{C} 3$ & Gram positive & 1366 & Bacillus siamensis strain MPF-C3 & MK949356 \\
\hline 21 & C5 & Gram negative & 1366 & Acetobacter ghanensis strain MPF-C5 & MK949357 \\
\hline 24 & D3 & Gram negative & 1432 & Vibrio alginolyticus strain MPF-D3 & MK949358 \\
\hline
\end{tabular}




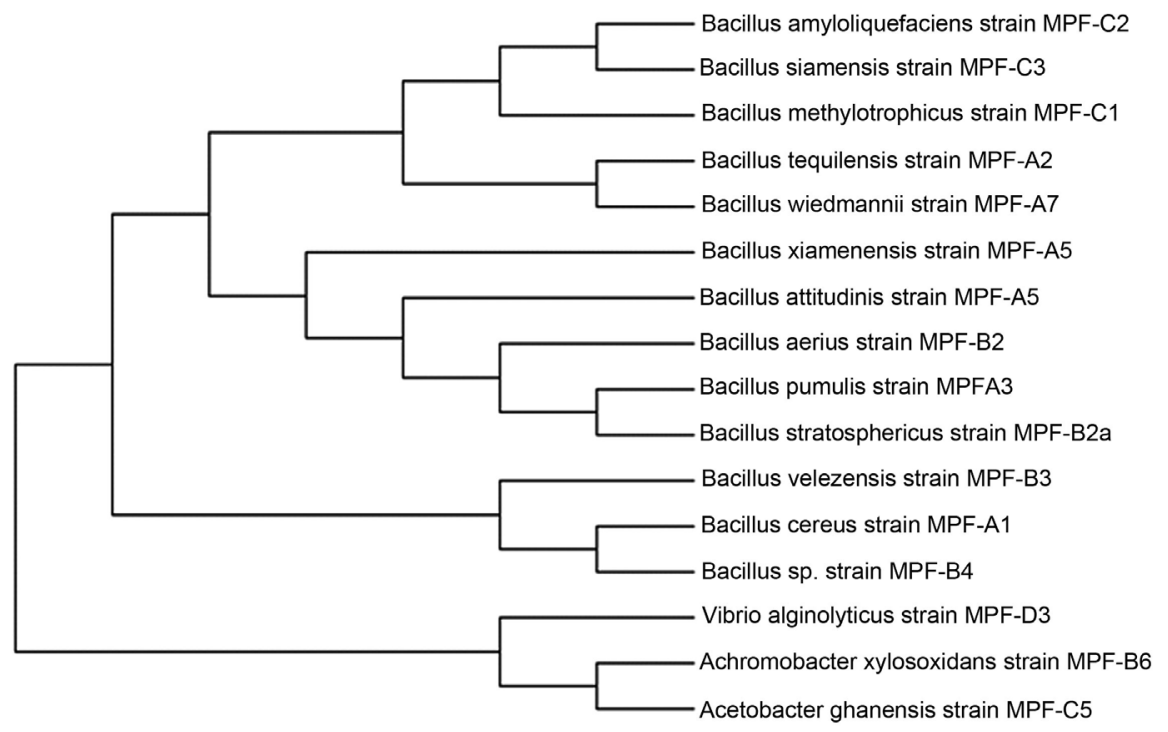

Figure 5. Molecular phylogenetic affinity analysis of $16 \mathrm{~S}$ rRNA gene sequences of organisms isolated from feeding waste of RPW larvae inside the trunk of date palm tree in Kingdom of Bahrain. The evolutionary history was inferred using Neighbor-Joining method [27]. The optimal tree with the sum of branch length $=0.29047318$ is shown. The phylogenetic tree is drawn to infer evolutionary distances. The evolutionary distances were computed using the Kimura 2-parameter method and are in the units of the number of translational substitution per site, while codon positions included were $1^{\text {st }}+2^{\text {nd }}+3^{\text {rd }}+$ Noncoding. All positions containing gaps and missing data were eliminated. The analysis included 16 nucleotide sequences and evolutionary analysis was conducted in MEGA 7 [28].

phylogenic relationship and evolutionary history was drawn using neighborjoining method [27] in MEGA7 software [28]. According to the 16S rRNA gene sequences, $B$. amyloliquefaciens strain MPF-C2, B. siamensis strain MPF-C3, $B$. methylotrophicus strain MPF-C1, B. tequilensis strain MPF-A2, B. wiedmannii strain MPF-B1a, all showed closeness and came in one clade in the phylogenic tree. The analysis of pairwise distance data and evolutionary divergence between the sequences uses the Kimura-2-parameter following transitions and transversions of the codons as mentioned in program. It showed $67 \%, 70 \%$ and $70 \%$ distance between $B$. amyloliquefaciens and the sequences of $V$. alginolyticus strain MPFD3, Acetobacter ghanensis strain MPF-C5, Achromobacter xylosoxidans strain MPF-B6 respectively within their evolutionary history.

The phylogenetic relationship was studied using $16 \mathrm{~S}$ rRNA gene sequences, the Gram-negative bacteria came in one clade while Gram-positive different $\mathrm{Ba}$ cillus sp. of different strains showed evolutionary closeness to each other and accordingly, they came in one major clade under three different sub-clades in the phylogenetic tree (Figure 5).

\section{Discussion}

\subsection{Impact of $16 \mathrm{~S}$ rRNA Sequence Analysis}

The identification of bacteria was done by using $16 \mathrm{~S}$ rRNA gene sequence analy- 
sis using NCBI site with comparison (Table 3 and Table 4). Comparison of the bacterial 16S rRNA gene sequence has characterized as a preferred genetic technique to identify poorly described, rarely isolated, or phenotypically aberrant strains of bacteria from any source [29] [30]. Sequence identity searching, specifically using the BLAST program in NCBI, is the most widely used and most reliable, for identifying and characterizing newly determined sequences with great reliability [31]. Among the culture-dependent isolated bacteria, $80 \%$ were identified by comparing $16 \mathrm{~S}$ rRNA gene sequence in NCBI database, using BLAST. Among the identified bacteria, $85 \%$ were Gram-positive while the rest of them were Gram-negative. A high abundance of bacteria from the Bacillaceae family of Firmicutes phylum and sixteen different species of Bacillus were identified in comparison with NCBI GenBank. Other Gram-negative bacteria belong to Phylum Proteobacteria of three different families.

\subsection{Identified Bacteria and Phylogenetic Relation}

The highest percentage of identified bacteria was of different Bacillus sp. of different strains that were present in feeding waste of RPW. There are several reports on RPW gut microbiota where mostly Bacillus sp. together with other bacteria observed. Those bacteria play an important role in RPW's digestive system, nutrient absorption, degradation of lignocellulose, and their survival [13] [23] [32]. Several Bacillus sp has great medical, biotechnological and economic importance [33]. They are resistant to heat, radiation, chemicals, oxidizing agents and desiccation, due to spore production, which is an important condition for their adaptation to different ecological niches [34]. The identified organism $B$. tequilensis strain MPF-A2 showed a $99 \%$ sequence identity with $B$. tequilensis strain HBUM07078 and Bacillus subtilis strain 5723. Similarly, B. tequilensis sp. nov., showed close realation with Bacillus subtilis [35]. In another report, $B$. tequilensis GYLH001 regarded as endophytic bacteria and was used as biocontrol agent of fungus Magnaporthe oryzae causing rice blast [36]. Moreover, Bacillus altitudinis P-10 worked as potential bioprotectant against Xanthomonas oryzae pv. oryzae, isolated from rice rhizosphere in Java, Indonesia [37]. B. altitudinis, B. xiamenensis and B. pumilus are the phenotypically and genotipically very closely related species and they produce acid from cellobiose, glucose and mannose [38]. B. aerius and B. stratosphericus are recognized as enzyme producers with probiotic activity inindustrial uses [37]. Several Bacillus sp. viz. B. megaterium, B. laterosporus and B. sphaericus were isolated from natural habitats associated with RPW insect-damaged date palms in Egypt and their bioassay showed 40\% - 60\% killing of RPW larvae in feeding study [23]. Considering the huge economic and environmental damage caused by RPW, some attention has been paid to the efficacy of different chemical and biocontrol strategies [39] in regard to several bacterial species to use as biological control [10] [20].

In the phylogenetic study, the Gram-negative bacteria came in one clade while 
Gram-positive Bacillus sp. showed evolutionary closeness to each other and accordingly they came under one main clade with three different sub-clades in the phylogenetic tree.

\section{Conclusion}

Red palm weevil (RPW) is one of the major insect pests of date palm. In the current study, different bacteria were isolated and identified based on 16S rRNA sequence from the feeding waste of RPW. The identified strains of bacteria are mostly different species of Bacillus. As different studies showed the great significance of Bacillus spp. in infection control, this study intensifies the searching of new biocontrol agent of RPW pest management program.

\section{Acknowledgements}

The research was supported by the Research Grant \# "LS_AA_2017" from College of Graduate studies, Agricultural Biotechnology Program, Department of Life Sciences, Arabian Gulf University. The authors would like to thank Mr. Ahmed Ali Al-Asfoor, Plant Wealth Directorate, Agriculture Affairs, Ministry of Work, Municipalities and Urban Planning, for the technical help in the field and processing of red palm weevil feeding waste samples. We like to Acknowledge Mr. Ali Ebrahim Al-Mahmeed, AGU and Xcelrislabs, India for their support in analysis.

\section{Conflicts of Interest}

The authors declare no conflict of interest.

\section{References}

[1] Giblin-Davis, R. and Roda, A. (2013) Real Time Internet Invasive Pest Identification Training: A Case Study with Rhynchophorus Weevils. Florida Entomologist, 96, 741-745. https://doi.org/10.1653/024.096.0306

[2] Dembilio, O., Jacas, J.A. and Llacer, E. (2009) Are the Palms Washingtonia filifera and Chamaerops humilis Suitable Hosts for the Red Palm Weevil, Rhynchophorus ferrugineus (Col. Curculionidae)? Journal of Applied Entomology, 133, 565-567. https://doi.org/10.1111/j.1439-0418.2009.01385.x

[3] El-mergawy, R., Nasr, M.I., Abdallah, N. and Silvain, J.F. (2011) Mitochondrial Genetic Variation and Invasion History of Red Palm Weevil, Rhynchophorus ferrugineus (Coleoptera; Crrculionidae), in Middle-East and Mediterranean Basin. International Journal of Agriculture and Biology, 13, 631-637.

[4] Fiaboe, K.K.M., Peterson, A.T., Kairo, M.T.K. and Roda, A.L. (2012) Predicting the Potential Worldwide Distribution of the Red Weevil, Rhynchophorus ferrugineus (Olivier) Coleoptera: Curculionidae Using Ecological Niche Modeling. Florida Entomologist, 95, 659-673. https://doi.org/10.1653/024.095.0317

[5] Wang, G., Zhang, X., Hou, Y. and Tang, B. (2015) Analysis of the Population Genetic Structure of Rhynchophorus ferrugineus in Fujian, China, Revealed by Microsatellite Loci and Mitochondrial COI Sequences. Entomologia Experimentalis et Applicata, 155, 28-38. https://doi.org/10.1111/eea.12282 
[6] Long, S. (2006) The Asian Red Palm Weevil, a Serous Pest of Canary Palm in Sicily. Informatore Fitopatologico, 56, 40-44.

[7] Almansoori, T., Al-Khalifa, A.M. and Mohamed, A. (2015) Date Palm Status and Perspective in Bahrain, p.353-386. In: Al-Khayri, J., Jain, S. and Johnson, D., Eds., Date Palm Genetic Resources and Utilization, Springer, Dordrecht, 353-386. https://doi.org/10.1007/978-94-017-9707-8_11

[8] Bokhari, U.G. and Abuzuhira, R. (1992) Diagnostic Tests for Redpalm Weevil, Rhynchophorus ferrugineus Infested Date Palm Trees. Arab Journal of Scientific Research, 10, 93-104.

[9] Faleiro, J. (2006) A Review of the Issues and Management of the Red Palm Weevil Rhynchophorus ferrugineus (Coleoptera: Rhynchophoridae) in Coconut and Date Palm during the Last One Hundred Years. International Journal of Tropical Insect Science, 26, 135-154.

[10] Valzano, M., et al. (2012) Deciphering Microbiota Associated to Rhynchophorus ferrugineus in Italian Samples: A Preliminary Study. Journal of Entomological and Acarological Research, 44, 85-89. https://doi.org/10.4081/jear.2012.e16

[11] Kaakeh, W. (2006) Toxicity of Imidacloprid to Developmental Stages of Rhynchophorus ferrugineus (Curculionidae: Coleoptera): Laboratory and Field Tests. Crop Protection, 25, 432-439. https://doi.org/10.1016/j.cropro.2005.07.006

[12] Murphy, S.T. and Briscoe, B.R. (1999) The Red Palm Weevil as an Alien Invasive: Biology and the Prospects for Biological Control as a Component of IPM. Biocontrol News and Information, 20, 35-45.

[13] Khiyami, M. and Alyamani, E. (2008) Aerobic and Facultative Aneorobic Bacteria from Gut of Red Palm Weevil (Rhinocophorus ferrugineus). African Journal of Biotechnology, 7, 1432-1437.

[14] Engel, P. and Moran, N.A. (2013) The Gut Microbiota of Insects: Diversity in Structure and Function. FEMS Microbiology Reviews, 37, 699-735. https://doi.org/10.1111/1574-6976.12025

[15] Tagliavia, M., et al. (2014) The Gut Microbiota of Larvae of Rhinochophorus ferrugineus Olivar (Coleoptra: Curculionidae). BMC Microbiology, 14, Article No. 136. https://doi.org/10.1186/1471-2180-14-136

[16] Muhammad, A., et al. (2017) The Gut Entomotype of Red Palm Weevil Rhynchophorus ferrugineus Olivier (Coleoptera: Dryophthoridae) and Their Effect on Host Nutrition Metabolism. Frontiers in Microbiology, 8, 2291.

https://doi.org/10.3389/fmicb.2017.02291

[17] Hosokawa, T., et al. (2015) Nardonella Endosymbionts of Japanesepest and Non-Pest Weevils (Coleoptera: Curculionidae). Applied Entomology and Zoology, 50, 223-229. https://doi.org/10.1007/s13355-015-0326-y

[18] Jia, S., et al. (2013) Seasonally Variable Intestinal Metagenomes of the Red Palm Weevil (Rhynchophorus ferrugineus). Environmental Microbiology, 15, 3020-3029. https://doi.org/10.1111/1462-2920.12262

[19] Berenbaum, M. (2003) Frass-Eating Grins. American Entomologist, 49,132-133. https://doi.org/10.1093/ae/49.3.132

[20] Butera, G., et al. (2012) The Cultural Bacterial Community of Frass Produced by Larvae of Rhynchophorus ferrugineus Olivier (Coleoptera: Curculionidae) in the Canary Island Date Palm. Letters in Applied Microbiology, 54, 530-536. https://doi.org/10.1111/j.1472-765X.2012.03238.x

[21] Ogbulie, T.E., Ogbulie, J.N. and Njoku, H.O. (2007) Comparative Study on the Shelf 
Life Stability of Palm Wine from Elaeisguineensis and Raphiahookeri Obtained from Okigwe, Nigeria. African Journal of Biotechnology, 6, 914-922.

[22] Naknean, P., Meenune, M. and Roudaut, G. (2010) Characterization of Palm Sap Harvested in Songkhla Province, Southern Thailand. International Food Research Journal, 17, 977-986.

[23] Salama, H.S., Foda, M.S., El-Bendary, M.A. and Razek, A.A. (2004) Infection of Red Palm Weevil, Rhynchophorus ferrugineus, by Spore-Forming Bacilli Indigenous to Its Natural Habitat in Egypt. Journal of Pest Science, 77, 27-31. https://doi.org/10.1007/s10340-003-0023-4

[24] Britschgi, T.B. and Giovannoni, S.J. (1991) Phylogenetic Analysis of a Natural Marine Bacterioplankton Population by rRNA Gene Cloning and Sequencing. Applied and Environmental Microbiology, 57, 1707-1713.

https://doi.org/10.1128/AEM.57.6.1707-1713.1991

[25] DeLong, E.F., Franks, D.G. and Alldredge, A.L. (1993) Phylogenetic Diversity of Aggregate-Attached vs. Free-Living Marine Bacterial Assemblages. Limnology and Oceanography, 38, 924-934. https://doi.org/10.4319/lo.1993.38.5.0924

[26] Weidner, S., Arnold, W. and Puhler, A. (1996) Diversity of Uncultured Microorganisms Associated with the Seagrass Halophilastipulacea Estimated by Restriction Fragment Length Polymorphism Analysis of PCR-Amplified 16S rRNA Genes. Applied and Environmental Microbiology, 62, 766-771.

https://doi.org/10.1128/AEM.62.3.766-771.1996

[27] Saitou, N. and Nei, M. (1987) The Neighbor-Joining Method: A New Method for Reconstructing Phylogenetic Trees. Molecular Biology and Evolution, 4, 406-425.

[28] Edgar, R.C. (2004) MUSCLE: Multiple Sequence Alignment with High Accuracy and High Throughput. Nucleic Acids Research, 32, 1792-1797. https://doi.org/10.1093/nar/gkh340

[29] Kolbert, C. and Persing, D. (1999) Ribosomal DNA Sequencing as a Tool for Identification of Bacterial Pathogens. Current Opinion in Microbiology, 2, 299-305. https://doi.org/10.1016/S1369-5274(99)80052-6

[30] Clarridge, J.E. (2004) Impact of 16S rRNA Gene Sequence Analysis for Identification of Bacteria on Clinical Microbiology and Infectious Diseases. Clinical Microbiology Reviews, 17, 840-862. https://doi.org/10.1128/CMR.17.4.840-862.2004

[31] Pearson, W.R. (2013) An Introduction to Sequence Similarity ("Homology”) Searching. Current Protocols in Bioinformatics.

[32] Shangang, J., et al. (2013) Seasonally Variable Intestinal Metagenomes of the Red Palm Weevil (Rhynchophorus ferrugineus). Environmental Microbiology, 15, 3020-3029.

[33] Logan, N.A. and De Vos, P. (2009) Genus Bacillus Cohn 1872. In: De Vos, P., et al., Eds., Bergey's Manual of Systematic Bacteriology, 2nd Edition, Vol. 3, Springer, New York, 21-128.

[34] Stackebrandt, E. and Swiderski, J. (2008) From Phylogeny to Systematics: The Dissection of the Genus Bacillus. In: Berkeley, R., et al., Eds., Applications and Systematics of Bacillus and Relatives, Blackwell Science, Oxford, 8-22. https://doi.org/10.1002/9780470696743.ch2

[35] Gatson, J.W., et al. (2006) Bacillus tequilensis sp. nov., Isolated from a 2000-YearOld Mexican Shaft-Tomb, Is Closely Related to Bacillus subtilis. International Journal of Systematic and Evolutionary Microbiology, 56, 1475-1484. https://doi.org/10.1099/ijs.0.63946-0

[36] Li, H., et al. (2018) Isolation and Evaluation of Endophytic Bacillus tequilensis 
GYLH001 with Potential Application for Biological Control of Magnaporthe oryzae. PLoS ONE, 13, e0203505. https://doi.org/10.1371/journal.pone.0203505

[37] Budiharjo, A., et al. (2017) Complete Genome Sequence of Bacillus altitudinis P-10, a Potential Bioprotectant against Xanthomonasoryzaepv. oryzae, Isolated from Rice Rhizosphere in Java, Indonesia. Genome Announcements, 5, e01388-17. https://doi.org/10.1128/genomeA.01388-17

[38] Branquinho, R., et al. (2014) Bacillus invictae sp. nov., Isolated from a Health Product. International Journal of Systematic and Evolutionary Microbiology, 64, 3867-3876. https://doi.org/10.1099/ijs.0.067850-0

[39] Pu, Y., Ma, T., Hou, Y. and Sun, M. (2017) An Entomopathogenic Bacterium Strain, Bacillus thuringiensis, as a Biological Control Agent against the Red Palm Weevil, Rhynchophorus ferrugineus (Coleoptera: Curculionidae). Pest Management Science, 73, 494-1502. https://doi.org/10.1002/ps.4485 